\title{
KEPRIBADIAN TOKOH TRITAGONIS DALAM NOVEL TENTANG KAMU KARANGAN TERE LIYE PERSPEKTIF PSIKOLOGI SASTRA SERTA IMPLIKASINYA TERHADAP PEMBELAJARAN SASTRA DI SMA
}

\author{
Annisa Amalia \\ SMPIT Shidqia Islamic School \\ E-mail: ninisamalia16@gmail.com
}

\begin{abstract}
ABSTRAK
Penelitian ini bertujuan untuk mengetahui bentuk kepribadian yang terdapat dalam novel Tentang Кати karangan Tere Liye. Penelitian ini menggunakan metode deskriptif kualitatif dengan teknik analisis isi. Teori kepribadian individual oleh Alfred Adler digunakan sebagai teori untuk menemukan bentuk kepribadian dalam novel Tentang Кати. Hasil penelitian menunjukkan adanya kepribadian yang dimiliki oleh tokoh tritagonis di dalam novel Tentang Кати karangan Tere Liye. Perilaku yang mencerminkan kepribadian tokoh tritagonis ditemukan sebanyak 117 data. Bentuk kepribadian yang dominan dimiliki oleh tokoh tritagonis yaitu striving for superiority denganditemukan 42 data atausekitar 35,89\% dari keseluruhan data. Dominan striving for superiority karena dari tema novel yang menampilkan perjuangan seseorang sehingga ditemukan banyak perilaku proses berjuang dan pantang menyerah. Hal itu didukung oleh kebermanfaatan tokoh terhadap lingkungan pada aspek social interest, dibuktikan oleh gerakan yang menunjukkan psikologi tokoh pada unity of personality dan cara atau kebiasaan tokoh dalam menyelesaikan masalah untuk bertahan pada satu prinsip yaitu life of style. Adapun bentuk kepribadian yang tidak dominan yaitu subjective perception dan creative power yang hanya didapat 3 data dari masing-masing aspek. Tidak dominan subjective perception dan creative power karena aspek ini hanya berguna untuk mengontrol diri dan tidak berpengaruh pada kejadian di lingkungan sekitar. Penelitian ini berimplikasi pada pembelajaran teks novel kelas XII SMA, KD 3.9 dan 4.9 yang mempelajari isi dan kebahasaan teks novel serta merancang pembuatan teks novel.
\end{abstract}

Kata kunci: kepribadian tokoh, tokoh tritagonis, psikologi sastra 


\title{
PERSONALITY OF TRITAGONIC FIGURE IN NOVEL TENTANG KAMU BY TERE LIYE LITERATURE PSYCHOLOGY PERSPECTIVE AND ITS IMPLICATIONS ON LITERATURE LEARNING IN SENIOR HIGH SCHOOL
}

\begin{abstract}
This research aims to know the shape of the personalities figure in the novel Tentang Кати the work of Tere Liye.This research uses qualitative descriptive method with content analysis techniques. Individual personality theory by Alfred Adler used as theory to find personality in the novel about you. The results showed the existence of a personality that is owned by the character tritagonis in his novel. Behavior that reflects the personality of the character tritagonis was found as manyas 117 data. The formof the dominant personality possessed by the tritagonis character that is striving for superiority with found data 42 or about $35.89 \%$ of the overall data. Striving for superiority is dominant because of the novel's theme showing the struggle of a person so found many behavioral processes of struggle and perseverance. It is supported by the advantage character of the environment in aspects of social interest, evidenced by the movement that shows the psychology of characters on the unity of personality and the ways people in habitorsolve the problem to persistin one principle i.e. life of style. As for the formof a dominant personality that issu objective perception and creative power that is only obtained 3 data from each aspect. Dominant not subjective perception and creative power because this aspect is only use ful to control them selves and have no effecton the incidencein the surrounding environment. The studies have implications for the study of the text of the novel in class XII high school, KD 3.9 and 4.9 which studies linguistic content and text of the novel as well as making text designing novel.
\end{abstract}

Keywords: personality, tritagonis character, the psychology literature

\section{PENDAHULUAN}

Setiap orang tentu memiliki suatu kepribadian. Kepribadian adalah suatu tingkah laku atau perilaku. Perilaku yang baik atau buruk bergantung pada manusia itu sendiri. Kepribadian dapat didasari oleh latar belakang keluarga, teman sepermainan, pengetahuan, serta wawasan. Latar belakang keluarga sering dianggap sebagai peran nomor satu dalam kepribadian seseorang, namun kepribadian seseorang sebenarnya masih dapat berubah. Perubahan itu dipengaruhi oleh lingkungan sekitar yaitu teman 
sepermainan, pengetahuan dan wawasan. Pengetahuan dan wawasan seseorang juga dapat dilihat dari kebiasaan yang sering dilakukan, salahsatunyaadalahkegiatan membaca. Salah satu sumber bacaan yang dapat mempengaruhi kepribadian adalah novel.

Novel adalah salah satu bentuk karya sastra yang menceritakan cerita fiksi, namun berasal dari kehidupan sehari-hari. Hal ini selaras dengan pendapat Tarigan dalam bukunya The American Collage Dictionary bahwa novel adalah suatu cerita prosa yang fiktif dalam panjang tertentu yang melukiskan para tokoh, gerak serta adegan kehidupan nyata yang representatif dalam suatu alur atau suatu keadaan yang agak kacau atau kusut. Senada dengan Tarigan, Nurgiyantoro mengatakan bahwa novel menggambarkan tokoh nyata, tokoh yang berasal dari realitas sosial. Dengan kata lain, novel memiliki kekuatan dalam memberikan pengaruh-pengaruh psikologi pada pembacanya. Pengaruh tersebut dapat bersifat baik atau buruk tergantung pada novel yang dibaca.

Untuk melihat kualitas sebuah novel, dapat dilihat dari konsisten atau tidaknya seorang penulis dalam menulis novel. Tere Liye secara konsisten menulis novel sehingga mendapatkan penghargaan Writer of The Year dari Ikatan Penerbit Indonesia. Novel Tentang Kamu layak dijadikan sumber belajar untuk di SMA karena novel ini merupakan novel populer. Novel ini menggunakan kosa kata yang mudah dipahami oleh pembaca, menampilkan permasalahan yang dapat diterima akal, dan terdapat unsur menghibur di dalamnya.

Pembentukan kepribadian tercantum dalam UU Nomor 20 tahun 2003 tentang Sistem Pendidikan Nasional Bab 1 pasal 1 tetang ketentuan umum bahwa:

AKSIS Jurnal Pendidikan Bahasa dan Sastra Indonesia

Volume 2 Nomor 2, Desember 2018 e-ISSN: 2580-9040

e-Journal: http://doi.org/10.21009/AKSIS 
Pendidikan adalah usaha sadar dan terencana untuk mewujudkan suasana belajar dan proses pembelajaran agar peserta didik secara aktif pengembangkan potensi dirinya untuk memiliki kekuatan spiritual keagamaan, pengendalian diri, kepribadian, kecerdasan, akhlak mulia, serta keterampilan yang diperlukan dirinya, masyarakat, bangsa dan negara.

Dari pasal yang tercantum pada Undang-Undang Sistem Pendidikan Nasional, pemerintah meluruskan pandangan bahwa sekolah tidak hanya mengembangkan potensi pada diri, namun juga kepribadian pada siswa. Mengembangkan kepribadian siswa dapat dilakukan melalui pembelajaran Bahasa Indonesia.

Pembelajaran bahasa mencakup aspek bahasa dan sastra. Tujuan pengajaran umum bahasa dan sastra Indonesia, yaitu siswa mampu menikmati, menghayati, memahami, dan memanfaatkan karya sastra untuk mengembangkan kepribadian, memperluas wawasan kehidupan, memperhalus budi pekerti, serta meningkatkan pengetahuan dan kemampuan berbahasa dalam proses mengajar dan mendidik siswa. Pada kurikulum 2013 mata pelajaran Bahasa dan Sastra Indonesia untuk SMA, Standar Kompetensi (SK) mata pelajaran Bahasa dan Sastra Indonesia terdiri beberapa subaspek mendengarkan, berbicara, membaca, dan menulis. Dalam silabus kurikulum 2013, ditemukan kompetensi mengenai pembelajaran sastra, khususnya novel dengan Kompetensi Dasar 3.9 Menganalisis isi dan kebahasaan novel pada siswa SMA. Melalui kompetensi dasar tersebutdapatdimasukkan aspek pembelajaran melalui menelaah kepribadian tokoh dalam novel. Novel yang akan digunakan adalah novel Tentang Кати karangan Tere Liye dengan menggunakan pendekatan psikologi sastra.

Kepribadian diartikan sebagai penggambaran tingkah laku secara deksriptif tanpa memberi nilai. Berbeda dengan karakter yang diartikan sebagai penggambaran tingkah 
laku dengan menonjolkan nilai benar salah atau baik buruk secara eksplisit maupun implisit. Teori psikologi Adler disebut sebagai psikologi individual. Adler memandang kesadaran sebagai pusat kepribadian seseorang, bukan ketidaksadaran. Psikologi indivual Adler memandang individu sebagai makhluk yang saling tergantung secara sosial. Ada enam pokok teori psikologi individual Adler yaitu: (1) perjuangan untuk sukses atau menjadi superior (striving for superiority), (2) persepsi subyektif individu untuk membentuk tingkah laku dan kepribadian (subjective perception), (3) semua fenomena psikologis disatukan di dalam diri individu (unity of personality), manfaat dari aktivitas manusia harus dilihat dari sudut pandang sosial (social interest, (5) semua potensi manusia dikembangkan sesuai dengan gaya hidup (life of style, dan (6) gaya hidup dikembangkan melalui kekuatan kreatif (creative power). Kepribadian akan mencerminkan keadaan psikologis seseorang yang dilihat dari cara individu berinteraksi. Hal ini yang akan diamati pada tokoh dan penokohan dalam novel Tentang Кати. Materi novel dalam pembelajaran Bahasa Indonesia seringkali hanya fokus pada tokoh protagonis dan antagonis. Tokoh tritagonis seringkali tidak dianggap penting dalam sebuah novel. Padahal, tokoh tritagonis memiliki kaitan dalam penceritaan. Tokoh tritagonis yaitu sebuah tokoh yang bersifat sebagai penengah, pendamai, atau dapat dipercaya oleh tokoh protagonis maupun antagonis. Oleh sebab itu, penelitian ini difokuskan pada tokoh tritagonis.

Berdasarkan uraian di atas, penelitian terhadap analisis aspek kepribadian tokoh tritagonis dirasa penting untuk diteliti.Tokoh tritagonis yang akan diteliti yaitu dalam novel Tentang Кати karangan Tere Liye dengan perspektif psikologi sastra dan implikasinya terhadap pengajaran sastra di sekolah menengah atas. 


\section{METODE}

Penelitian ini merupakan penelitian kualitatif dengan analisis isi karya sastra. Penelitian ini dibantu tabel analisis untuk memudahkan analisis data. Tabel analisis memuat kutipan perilaku yang dilakukan tokoh tritagonis. Kutipan dibatasi hanya kutipan yang mengandung kepribadian tokoh tritagonis di dalamnya, sehingga penggunaan kutiapan yang tidak diperlukan tidak dimasukkan ke dalam tabel analisis.

Objek yang digunakan dalam penelitian ini adalah novel Tentang Kamu karangan Tere Liye untuk mencari kalimat-kalimat yang berhubungan dengan kepribadian tokoh. Analisis data kepribadian dibantu dengan teori kepribadian individual oleh Alfred Adler.

Teknik yang digunakan dalam penelitian ini yaitu dengan cara menentukan tokoh tritagonis. Lalu, mengidentifikasi kutipan-kutipan yang berkaitan dengan kepribadian tokoh tritagonis. Setelahitu, memasukkan dalam tabel analisis dan dianalisis. Kemudian menganalisis berdasarkan teori kepribadian yang digunakan. Selanjutnya memberikan interpretasi dari analisis dan terakhir memberikan simpulan.

\section{HASIL DAN PEMBAHASAN}

Hasil analisis yang ditemukan oleh peneliti menunjukkan bahwa pada bentuk kepribadian yang dominan pada tokoh tritagonis yaitu Zaman Zulkarnaen yaitu perjuangan untuk sukses atau menjadi superior (striving for superiority). Bentuk kepribadian (1) perjuangan untuk sukses atau menjadi superior (striving for superiority), (2) persepsi subjektif individu untuk membentuk tingkah laku dan kepribadian (subjective perception), (3) semua fenomena psikologis disatukan di dalam diri individu (unity of personality), (4) manfaat dari aktivitas manusia harus dilihat dari 
sudut pandang sosial (social interest, (5) semua potensi manusia dikembangkan sesuai dengan gaya hidup (life of style), dan (6) gaya hidup dikembangkan melalui kekuatan kreatif (creative power) dipengaruhi oleh diri sendiri dan peran lingkungan. Bentuk kepribadian dapat didistribusikan melalui perilaku sesuai dengan yang dibutuhkan oleh diri dan lingkungan.

Tabel 4.4

Rekap Data Kepribadian Tokoh Tritagonis dalam Novel Tentang Kamu karangan Tere Liye

\begin{tabular}{|c|c|c|c|c|c|c|}
\hline KriteriaAnalisis & $\mathbf{1}$ & $\mathbf{2}$ & $\mathbf{3}$ & $\mathbf{4}$ & $\mathbf{5}$ & $\mathbf{6}$ \\
\hline Jumlah & 42 & 3 & 22 & 36 & 11 & 3 \\
& & & & & & \\
\hline Persentase & $35,89 \%$ & $2,56 \%$ & $18,80 \%$ & $30,76 \%$ & $9,40 \%$ & $2,56 \%$ \\
\hline
\end{tabular}

Berdasarkan tabel 4.4, dapat terlihat dalam novel Tentang Kamu karangan Tere Liye mencakup hasil data keseluruhan kepribadian tokoh tritagonis dalam novel Tentang Кати meliputi beberapa bagian di dalamnya, yaitu perjuangan untuk sukses atau menjadi superior (striving for superiority), persepsi subjektif individu untuk membentuk tingkah laku dan kepribadian (subjective perception), fenomena psikologis disatukan di dalam diri individu (unity of personalityt), manfaat dari aktivitas manusia harus dilihat dari sudut pandang sosial (social interest), semua potensi manusia dikembangkan sesuai dengan gaya hidup (life of style), dan gaya hidup dikembangkan melalui kekuatan kreatif (creative power).

AKSIS Jurnal Pendidikan Bahasa dan Sastra Indonesia 
Novel Tentang Кати sebagai objek penelitian yang dianalisis, terdiri dari 524 halaman yang terbagi ke dalam 33 bagian. Terdapat 117 data kepribadian yang yang terbagi dalam 6 bagian kepribadian. Fokus penelitian yaitu kepribadian tokoh tritagonis. Data yang masuk ke dalam bagian kepribadian perjuangan untuk sukses atau menjadi superior (striving for superiority) berjumlah 42 data atau sekitar 35,89\%. Pada persepsi subjektif individu untuk membentuk tingkah laku dan kepribadian (subjective perception) ditemukan 3 data atau sekitar 2,56\%. Kemudian pada fenomena psikologis disatukan di dalam diri individu (unity of personality) ditemukan 22 data atau sekitar 18,80\%. Manfaat dari aktivitas manusia harus dilihat dari sudut pandang sosial (social interest) ditemukan 36 data atau sekitar 30,76\%. Kemudian bagian semua potensi manusia dikembangkan sesuai dengan gaya hidup (life of style) ditemukan 11 data atau sekitar 9,40\%. Terakhir, gaya hidup dikembangkan melalui kekuatan kreatif (creative power) ditemukan 3 data atau sekitar 2,56\%.

Kepribadian yang dominan yaitu perjuangan untuk sukses atau menjadi superior (striving for superiority) karena dari tema novel yang menampilkan perjuangan seseorang sehinggaditemukan banyak perilaku proses berjuang dan pantang menyerah. Hal itu didukung oleh sifat tokoh tritagonis yang pantang menyerah, berjuang secara total, juga kebermanfaatan tokoh tritagonis terhadap lingkungan.

Bentuk kepribadian perjuangan untuk sukses atau menjadi superior (striving for superiority) memiliki kekuatan terhadap bentuk kepribadian yang lain. Hal ini dibuktikan dengan perilaku yang mencerminkan bentukperjuangan untuk sukses atau menjadi superior (striving for superiority) akan berkaitan dengan perilaku sosial (social interest) karena secara tidak sadar berjuang untuk kepentingan diri sendiri dan orang sekitar telah menampilkan jiwa kepedulian seseorang terhadap kemaslahatan banyak 
orang. Setiap bentuk berjuang, menolong, menghargai, mengalah, berpikir, atau menyerah sekali pun akan menimbulkan gerakan yang menunjukkan psikologi tokoh tritagonis pada (unity of personality). Gerakan tersebut merupakan refleksi dari tokoh tritagonis dalam menmbentuk kepribadiannya. Refleksi tubuh yang secara sadar atau tidak merupakan kebiasaan atau cara yang sudah tertanam sejak dulu (life of style). Seluruh bentuk kepribadian yang sudah terjadi pada tokoh tritagonis yang telah dilakukan, maka akan memunculkan kepribadian lain dalam diri yaitu persepsi subjektif (subjctive perception) dan kekuatan kreatif (creative power). Dua bentuk kepribadian tersebut menjadi penyeimbang bentuk kepribadian pada tokoh tritagonis untuk mengontrol kepribadian yang dilakukan dan menjadi motivator kepribadian untuk keberlangsungan hidup yang lebih baik.

Kaitan antara tokoh tritagonis dan bentuk kepribadian yang dimiliki memiliki keterkaitan. Tokoh tritagonis tampil pada penceritaan tokoh sebagai pengurai sebuah masalah, pendamai, dan membantu penyelesaian tokoh protagonis dan tokoh antagonis. Maka tokoh tritagonis yaitu Zaman ditampilkan sebagai tokoh yang berwibawa dan bijaksana serta tidak ditampilkan sebagai sosok yang arogan. Tokoh tritagonis yang menjadi tokoh pendamai atau pengurai masalah akan membantu penyelesaian masalah, oleh sebab itu Zaman Zulkarnaen lebih dominan perjuangan untuk sukses atau menjadi superior (striving for superiority) dan diikuti dominan kedua yaitu perilaku sosial(social interest). Hal tersebut terjadi karena melalui kepribadian perjuangan untuk sukses atau menjadi superior (striving for superiority) Zaman menyelesaikan peramsalahan masa lalu tokoh protagonis yaitu Sri dengan tokoh antagonis yaitu Sulastri. Kebutuhan tokoh tritagonis dalam menyelesaikan masalah itu juga berkaitan dengan lingkungan sekitar 
yang mewajibkan tokoh tritagonis yaitu Zaman untuk berperilaku yang sesuai dengan norma.

\section{KESIMPULAN}

Berdasarkan penelitian yang telah dilakukan terhadap novel Tentang Kamu karangan Tere Liye mengenai kepribadian tokoh tritagonis yang ada di dalamnya yang terdiri atas (1) perjuangan untuk sukses atau menjadi superior (striving for superiority), (2) (subjective perception), (3) semua fenomena psikologis disatukan di dalam diri individu (unity of personality), (4) manfaat dari aktivitas manusia harus dilihat dari sudut pandang sosial (social interest, (5) semua potensi manusia dikembangkan sesuai dengan gaya hidup (life of style, dan (6) gaya hidup dikembangkan melalui kekuatan kreatif (creative power) maka dapat disimpulkan sebagai berikut:

Hasil penelitian ini ditemukan adanya bentuk kepribadian pada tokoh tritagonis yang dominan adalah perjuangan untuk sukses atau menjadi superior (striving forsuperiority) karena tokoh tritagonis dipengaruhi oleh perasaannya untuk melakukan sebuah perilaku yang baik dan bermanfaat untuk orang di sekitar. Perilaku tersebut bermanfaat untuk tokoh tritagonis dan lingkungan sekitarnya.

\section{UCAPAN TERIMA KASIH}

Penulis mengucapkan terima kasih kepada segenap pihak yang telah mendukung proses penelitian ini. 


\section{DAFTAR PUSTAKA}

Alwisol. (2009). Psikologi Kepribadian. Malang: UMM Press.

Depdiknas. (2007). Buku Praktis Bahasa Indonesia. Jakarta: Pusat Bahasa.

Nurgiyantoro, B. (2013). Teori Pengkajian Fiksi. Yogyakarta: Gadjah Mada University Press.

Purwahida, R. (2017). Interaksi sosial pada kumpulan cerpen Potongan Cerita di Kartu Pos karangan Agus Noor dan implikasinya terhadap pembelajaran sastra di SMA. 1(1). 118-134. Aksis: Jurnal Pendidikan Bahasa dan Sastra Indonesia, 1(1). doi: doi.org/10.21009/AKSIS.010107

Tarigan, H. G. (1995). Prinsip-Prinsip Dasar Sastra. Bandung: Angkasa. 